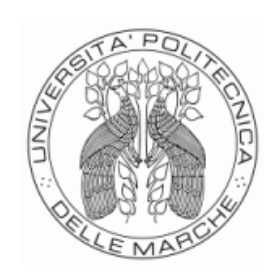

UNIVERSITÀ POLITECNICA DELLE MARCHE DIPARTIMENTO DI ECONOMIA

\title{
BOOSTING MANUFACTURING PRODUCTIVITY THROUGH R\&D: INTERNATIONAL COMPARISONS WITH SPECIAL FOCUS ON ITALY
}

ALESSANDRO STERLACCHINI AND FRANCESCO VENTURINI QUADERNO DI RICERCA n. 306 
Comitato scientifico:

Renato Balducci

Marco Crivellini

Marco Gallegati

Alberto Niccoli

Alberto Zazzaro

Collana curata da:

Massimo Tamberi 


\title{
BOOSTING MANUFACTURING PRODUCTIVITY THROUGH R\&D: INTERNATIONAL COMPARISONS WITH SPECIAL FOCUS ON ITALY
}

\author{
Alessandro Sterlacchini ${ }^{\mathrm{a}}$ and Francesco Venturini ${ }^{\mathrm{b}}$
}

\begin{abstract}
Using data for twelve manufacturing industries of five developed countries over the period 19802002, we perform a dynamic panel estimation - based on a ECM model - of the long-run elasticity of TFP with respect to the stock of R\&D capital. The highest elasticity is found for the US (0.51) while lower values arise for Germany (0.29), France (0.23) and Spain (0.22); the latter, in turn, are higher than that estimated for Italy (0.14). The unsatisfactory performance of Italian manufacturing industries is confirmed by further analyses in which a better measurement of TFP is provided and the time period extended. The above findings and their policy implications are discussed firstly in the light of the US-EU divide in terms of R\&D-induced productivity growth and, subsequently, by focussing on the Italian case.
\end{abstract}

Keywords: Productivity growth. R\&D capital stock. Manufacturing industries.

JEL Codes: O4, O3, L6.

${ }^{a}$ Corresponding author a.sterlacchini@univpm.it. Faculty of Economics, Università Politecnica delle Marche, Piazzale Martelli, 8, 60121 Ancona (Italy).

b f.venturini@univpm.it. Faculty of Economics, Università Politecnica delle Marche, Piazzale Martelli, 8, 60121 Ancona (Italy). 


\section{Introduction}

The main motivation of the present paper stems from the current debate on the weak productivity performance of European countries as opposed to that recorded, especially during the second half of the 1990s, in the US. Although a substantial share of the productivity gap is attributable to services, also the recent performance of European manufacturing industries has been disappointing. Both in the light of endogenous growth models and the empirical evidence across countries, industries and firms, the above productivity divide has been mainly ascribed to the lower accumulation of knowledge and human capital experienced in the EU countries. It is also on this basis that, in 2000, the European Council launched the Lisbon strategy. Accordingly, the subsequent Barcelona Council established, for 2010, the target of a 3\% share of R\&D expenditures on GDP for the whole EU. In this respect, a pivotal role must be played by the manufacturing sector since this is where the bulk of a country's R\&D is performed.

Among the largest European countries, Italy has experienced, over the last decade, a slowdown in total factor productivity (TFP) that has been particularly evident in manufacturing. Being coupled with decreasing shares in the international trade of industrial products, the reduction of productivity growth has pushed many scholars to contend that Italy is experiencing an 'industrial decline'. With respect to the causes of this phenomenon, most of them have pointed their fingers at the inadequate knowledge base of Italian firms. As a consequence, if the therapies designed within the Lisbon strategy are necessary for the whole EU, Italy should undertake exceptional efforts in terms of R\&D activities. The above argument is hardly debatable. However, for countries like Italy - characterised by a prevalence of low and medium-tech industries - there is little knowledge about the expected size of this R\&D-induced enhancement of TFP.

By using data for twelve manufacturing industries of five developed countries over the period 19802002, a dynamic panel analysis based upon an Error Correction Model (ECM) - able to disentangle the long-run effect of R\&D from short-run deviations - indicates that the long-run elasticity of TFP with respect to the stock of R\&D capital is higher in the US (0.51) than in Germany (0.29), France (0.23) and Spain (0.22); the latter, in turn, are stronger than that concerned with Italy (0.14). These findings support the need of a Lisbon-type of policy by suggesting that, if European countries want to attain the same productivity enhancement recorded among US industries, they must invest much more resources in R\&D. While the message for Germany, France and Spain seems quite clear, the same does not apply to Italy. In this case, the estimated long-run effect is so low that even with an 
increase of research expenditures four times bigger than that performed in the US the raise in TFP will be lower.

To be added is that, for Italy, we were able to control the robustness of the above results to the possible biases associated with measurement errors; so, in the ECM estimation, we used a TFP measure that accounts for the degree of utilisation and the qualitative level of labour and capital inputs. Moreover, we extended the econometric analysis over a longer period (1970-2002) with a view to increase the dynamic (time-series) properties of the estimation. Although the relationship remains positive and statistical significant, the low 'productivity' of R\&D across Italian manufacturing industries is confirmed. In fact, its long-run impact on TFP decreases slightly by using adjusted measures of capital and labour and significantly by extending the time-span of the estimation.

How to explain the anomalous performance of Italy? The widely used (and abused) interpretation relying on the low R\&D intensity recorded, on average, by Italian firms is discarded by the result arising for Spanish manufacturing (quite similar to the Italian one in terms of specialization and prevalence of small firms). Its average $R \& D$ intensity is lower than that performed in Italy but the elasticity of TFP with respect to R\&D capital turns out to be significantly higher (and not far from those found for Germany and France). An alternative and more plausible explanation relies, instead, on the declining R\&D efforts experienced, during the Nineties, by the Italian manufacturing industries. As it is well documented in the paper, such a declining (or, at best, stationary) trend is peculiar to Italy since all the other countries considered, especially from 1995 on, have significantly increased their R\&D investment.

Moving to policy considerations, our results could be used to conclude that, in the case of Italy (and contrary to the experience of either some leading countries or a technological follower like Spain) exceptional efforts in terms of $R \& D$ investment cannot produce, by themselves, a remarkable increase of productivity. However, according to our explanation, the weak relationship between R\&D and TFP arising for Italy is not due to structural (and, as such, not easily modifiable) features but is the outcome of a decade of slowdown in R\&D investment (the Nineties) after a decade of remarkable expansion (the Eighties). As a consequence, to say that R\&D activities are of little use for a country like Italy would be a very misleading conclusion. On the contrary, for its R\&D-based industries, there is a strong and urgent need to, at least, re-take the path of the Eighties. Although an R\&D-induced boost in productivity cannot be expected in the short-run and, probably, in the medium-run as well, to heavily invest in $R \& D$ is an inescapable condition to remain competitive in the long-run. 
The paper is organised as follows. Section 2 reviews the debate on the recent productivity slowdown experienced in the EU and Italian manufacturing. Section 3 introduces a standard production function framework for shaping the relationship between TFP changes and R\&D capital. Section 4 compares the R\&D intensity and capital stock across industries and countries. In section 5 , after checking the unit roots and cointegration properties of the series, we present the countryspecific estimates by employing an ECM to link TFP and R\&D capital across manufacturing industries. Section 6 performs a supplementary analysis of the Italian case. Section 7 provides a discussion of the main findings and their policy implications and suggests some possible extensions of the analysis.

\section{The productivity slowdown in the EU and Italian manufacturing: explanations and remedies}

The Lisbon strategy, launched by the European Council in 2000, is mainly based on the idea that the slow rate of productivity growth recorded during the last decade by EU countries (as opposed to the productivity revival experienced in the US) depends primarily upon their lower endowments of knowledge capital. In this respect, there is a broad consensus among economists on the crucial role of $R \& D$ investment.

In contrast to the standard neoclassical framework, endogenous growth models contend that longrun economic growth is influenced, rather than by exogenous technological changes, by the intentional accumulation of knowledge or R\&D (Romer, 1990). A large body of empirical evidence, either among countries (European Commission, 2005) or across industries and firms (Griliches, 1995; Wieser, 2005), supports the above arguments: no matter the units of observation, the returns from R\&D investments are substantial and provide to the performing units permanent rather than transitory advantages.

The current debate on the problematic economic prospects of the EU has been heavily influenced by the above arguments and findings. The Sapir report, for instance, contends that the catching up with the US, mainly based on imitation and accumulation of physical capital, was exhausted when the European countries moved closer to the technological frontier (Sapir et al., 2004). In the current phase, innovation at the frontier is the main engine of growth and this justifies the need of extraordinary investment in R\&D. To reinforce this line of argument, it can be stressed that, being the new technologies more complex and knowledge-intensive than in the past, it is difficult to exploit them effectively without an adequate knowledge base. Thus, R\&D activities are crucial not only to introduce innovation at the frontier but also to remain close to it, by maintaining an adequate absorption capacity (Cohen and Levinthal, 1989; Griffith et al., 2004). 
The same arguments are widely recalled in the current debate on the Italian 'industrial decline'. At a macro level, the decreasing contribution of TFP to the economic growth of Italy has been well documented by Jorgenson (2005) who shows that its productivity has been inexorably deteriorating since the early Eighties when the country, in terms of efficiency levels, was among the best performing economies. Daveri (2004) stresses that, from the mid-Nineties, the sluggish productivity performance has been a source of concern for the whole EU-15 and its decreasing rates of growth were mainly ascribable to non-durable manufacturing industries. However, Venturini (2004) finds that, in Italy, such a reduction is more severe than that experienced by its major EU partners. According to Bassanini et al. (2004), the rise of productivity has become negligible or even negative from 1996 to 2001, while it accounted for a very large share of the value added growth in the previous fifteen years. By extending the analysis up to 2003, Daveri and Jona-Lasinio (2006) confirm the above findings: the labour productivity slowdown experienced in Italy during the last decade is mainly due to TFP and the growth of the latter declined particularly (albeit not only) in manufacturing. By means of a panel cointegration analysis applied to Italian industries, Fachin and Gavosto (2007) show that the recent deviation of labour productivity from its long-run trend has been driven by the disappointing dynamics of TFP; the latter has been depressed by both factor reallocation processes and inadequate $\mathrm{R} \& \mathrm{D}$ efforts.

As a whole, these pieces of evidence, coupled with the decreasing shares in international trade recorded by the Italian manufacturing goods from 1995 on, indicate that the threat of an industrial decline is real and should be seriously addressed with appropriate policies. Among the latter, those grouped under the 'Lisbon strategy' label and focussed upon knowledge, human capital and regulatory reforms should receive a particular impulse (Boeri et al., 2005).

Leaving aside the role of regulatory reforms concerned with labour and product markets (which goes beyond the scope of the present paper), there is a broad consensus among Italian scholars and policy makers on the need of extra-ordinary efforts in the fields of human capital, knowledge and R\&D. The latter variable should be particularly effective in boosting the productivity of manufacturing industries, simply because, in all the most industrialised countries (Italy included), they account for more than $80 \%$ of business R\&D expenditures (cf. Zachariadis, 2004). Thus, manufacturing industries and firms should be the most suitable units of observation for studying the relationship between $R \& D$ and productivity growth.

During the last years, along with a dramatic increase of firm-level analyses, a number of studies with industry data have been carried out, such as Frantzen (2002), Griffith et al. (2004), Zachariadis (2004), Cameron (2005), Añón Higón (2007) and Brandt (2007). Among them, however, only Brandt compares across some OECD countries the results of an industry analysis (and provides 
estimates for Italy); Añón Higón focuses on UK manufacturing industries, Cameron examines the productivity gap between Japanese and US industries, while the remaining authors pool industry and country data without providing details on the results concerned with single economies.

In this paper, we employ data on twelve manufacturing industries over a period of twenty-three years (i.e. from 1980 to 2002) to perform separate econometric analyses for five of the major OECD states: namely, US, Germany, France, Spain and Italy. On average, the four European countries account for two thirds of the EU-15 levels of R\&D expenditure and GDP, so that, although a special focus shall be devoted to Italy, the findings and policy implications of our analysis will refer to a large portion of Europe. Moreover, the inclusion of Italy and Spain (whose manufacturing sectors recorded, over the period considered, a strong presence of medium- and low-tech industries) is particularly useful for testing whether the R\&D policy emphasised by the Lisbon strategy could be effective for a broad set of industrialised countries and not only for the most technology-advanced ones.

\section{Analytical framework and data description}

In order to shape the relationship between R\&D and TFP variables, the most widely used model is a Cobb-Douglas production function augmented with R\&D (or knowledge) capital (Hall, 2006), that is:

$$
Y_{i t}=A L_{i t}^{\alpha} K_{i t}^{1-\alpha} R D_{i t}^{\theta}
$$

where the suffixes $i$ and $t$ denote industries and years, $Y$ stands for value added at constant prices, $L$ is a measure of labour input, while $K$ and $R D$ denote, respectively, the stock of tangible and $R \& D$ capital. For 'traditional' inputs $L$ and $K$, constant returns to scale are assumed.

Taking logs and assuming perfectly competitive markets, so that labour and tangible capital are paid according to their marginal productivity and $\alpha$ can be proxied by the labour share on value added $s_{L}$, a measure of TFP can be computed and expressed as a function of the stock of R\&D capital:

$$
\ln T F P_{i t}=\ln Y_{i t}-s_{L i} \ln L_{i t}-\left(1-s_{L i}\right) \ln K_{i t}=\eta_{i}+\theta \ln R D_{i t}
$$

where $\eta_{i}$ is an industry specific effect, assumed constant over time, which should pick up any individual unobserved heterogeneity (due, for instance, to exogenous changes in technology, regulatory frameworks, etc.).

It must be stressed that, as far as the labour and capital inputs specifically devoted to R\&D are already included in $L$ and $K$ (i.e. the inputs on the right-hand side of equation [1] are not corrected for double counting), $\theta$ must be interpreted as the excess elasticity of value added with respect to 
R\&D capital. In other words, a positive value of this parameter should emerge only if the labour and capital inputs employed in the firms' $R \& D$ function are 'more productive' than those devoted to other functions (production, administration, and so on).

In order to estimate $\theta$, we consider twelve manufacturing industries in five countries for which the Structural Analysis (STAN) database of the OECD provides, over the period 1980-2002, consistent data (both at current and constant prices), on valued added, gross fixed capital formation, total employment and labour compensation.

For each industry, the stock of tangible capital $(K)$ is computed according to the perpetual inventory model and assuming a geometric depreciation; annual data are mid-year adjusted (as in van Ark et al., 2002). The initial $\left(\mathrm{t}_{1}=1980\right)$ capital stock is evaluated according to the procedure introduced by Hall and Mairesse (1995), $K_{i, 1}=I_{i, 1} /\left(\mathrm{g}_{\mathrm{i}}+\delta_{\mathrm{i}}\right)$, where $I_{i, 1}$ is the gross fixed capital formation (evaluated at 1995 constant prices) in industry $i$ at time 1 , and $g_{i}$ is the average annual growth rate of real investment over the subsequent decade (from $t_{1}=1980$ to $t_{10}=1990$ ). As in Mazzeffoli (2006), we estimate the depreciation rate $\delta_{i}$, constant over time, as the ratio between consumption of fixed capital and gross fixed capital stock provided by OECD at industry level ${ }^{1}$.

Having computed the stock of tangible capital, we use the data on valued added at 1995 prices, total employment (employees plus self-employed persons) and labour compensation on value added ${ }^{2}$ with a view to obtain, for each industry of the five countries considered, the annual log-level of TFP (as in equation [2]).

The next step refers to the computation of the R\&D capital stock. For the manufacturing industries of Germany, France, Spain and the US, we took the annual series of nominal expenditure on R\&D provided by OECD (cf. Appendix 1) and converted them into 1995 prices by means of the value added deflator of each industry. For Italian industries, instead, we used the R\&D data coming from ISTAT (the Italian Statistical Office), mainly because ${ }^{3}$ they are available since the late sixties, and then allowed us to extend the analysis of the Italian case to a longer period of time (see section 6). Also for computing the stock of R\&D capital at industry level we follow the perpetual inventory model based on annual outlays expressed at 1995 prices. However, contrary to the data on tangible

\footnotetext{
${ }^{1}$ The consumption of fixed capital is computed as the gross fixed capital formation at time $t$ minus the absolute variation of net capital stock between time $t$ and $t-1$. Net and gross fixed capital stocks are built by OECD through a permanent inventory method accounting for the age and efficiency profile of different capital assets. For Italy, France and Spain the period considered to estimate the depreciation rate spans from 1980 to 2002, while for Germany from 1991 onwards. For the US, due to the lack of data on net and gross fixed capital stock, the mean of the industry depreciation rates of the other countries is applied.

2 Labour compensation is augmented by the remuneration of self-employed workers by assuming that their compensation rate is equal to that of employees (OECD, 2001).

${ }^{3}$ The other reason for using the national source is that OCED data for Italian industries are re-adjusted. The observed discrepancies are not big in absolute terms but, for some Italian industries that spend very little on R\&D (see Table 1 below), they became non negligible.
} 
assets, R\&D expenditures at industry level are available since 1973 , so that we were able to evaluate the R\&D stock in 1980 by taking into account also the $R \& D$ efforts of the previous seven years. To be added is that the R\&D stock in 1973 is computed by applying the same procedure described above although, in this case, we assume a depreciation rate of 15 per cent, constant across industries. Such a depreciation rate is the one usually taken to build the R\&D capital stock at firm and industry level (cf. Hall and Mairesse, 1995). In any case, as far as the growth and the depreciation rate of $R \& D$ outlays do not significantly change over time, the differences among industries will be incorporated into the fixed effect ( $\eta_{i}$ in equation [2]), so that the estimated elasticity of TFP with respect to $R \& D$ capital $(\theta)$ will not be affected by the choice of a different depreciation rate (Hall, 2006).

\section{Comparing R\&D performances across industries and countries}

To highlight the differences among industries and countries, we first employ the share of R\&D expenditures on value added (at current prices). Although, according to the previous section, our analysis is focussed on R\&D capital, the intensity indicator is more effective for descriptive purposes and extensively used for static comparisons of technological performances.

Table 1 illustrates the R\&D intensity, averaged over 1980-2002, of the twelve manufacturing industries ${ }^{4}$ examined in the present study. For the majority of them the leading country is the US, which records for the whole manufacturing sector an $8.5 \%$ share of research expenditures. Although characterised by a lower aggregate intensity of R\&D, Germany and France equalise or slightly overcome the performance of the US in some industries: this occurs especially in Chemicals \& Pharmaceuticals, but the French performance is quite good also in Transport and Electrical \& Optical Equipment. On the contrary, in all the industries considered Italy attained a much lower intensity of R\&D outlays: only in Transport Equipment and only when opposed to Germany the Italian gap is not pronounced. Consequently, the still persistent idea that the low research intensity of Italy is mainly attributable to its strong specialisation in low-tech or 'supplier dominated' industries is not supported by the data. Even in the typical research-intensive industries, Italian firms devote to R\&D half of the share of value added invested in the most industrialised countries. Moving to Spain, a very low intensity of R\&D emerges in almost all the sectors. Compared to Italy, the R\&D investment of this country has been weaker in high-tech industries and moderately

\footnotetext{
${ }^{4}$ Both in the aggregate descriptive statistics and in the subsequent regression analysis we exclude the industry of Coke, Refined Petroleum Products \& Nuclear Fuel for its erratic and anomalous behaviour in terms of productivity and R\&D performances (especially during the first part of the period considered). Depending on the country taken into consideration, econometric results are sensitive to the inclusion of this industry.
} 
stronger in most low- and medium-tech ones (in particular, Spain stands out for a relatively high intensity of research expenditures in Machinery).

Table 1 - R\&D intensity on value added by industry: average 1980-2002 (current prices)

\begin{tabular}{lrrrrc}
\hline & US & Germany & France & Italy & Spain \\
\hline Food, Beverage \& Tobacco & 1.2 & 0.6 & 0.9 & 0.3 & 0.4 \\
Textile, Clothing \& Leather & 0.6 & 1.2 & 0.7 & 0.1 & 0.3 \\
Wood \& Wood Products & 1.1 & 1.1 & 0.3 & 0.1 & 0.1 \\
Paper, Printing \& Publishing & 0.8 & 0.3 & 0.3 & 0.1 & 0.2 \\
Chemicals \& Pharmaceuticals & 12.7 & 13.4 & 12.7 & 5.9 & 3.5 \\
Rubber \& Plastics Products & 2.7 & 2.5 & 4.0 & 1.6 & 1.3 \\
Non-metallic Mineral Products & 2.3 & 1.8 & 1.8 & 0.2 & 0.4 \\
Basic Metals \& Fabricated Metal Products & 1.5 & 1.8 & 1.6 & 0.6 & 0.6 \\
Machinery \& Equipment N.E.C. & 15.0 & 5.7 & 3.8 & 1.4 & 1.8 \\
Electrical \& Optical Equipment & 18.2 & 12.3 & 17.3 & 7.6 & 5.2 \\
Transport Equipment & 21.7 & 14.5 & 20.3 & 11.1 & 3.9 \\
Other manufacturing industries & 1.5 & 0.7 & 0.9 & 0.2 & 0.4 \\
\hline Total manufacturing* & 8.5 & 6.6 & 6.5 & 2.3 & 1.5 \\
*=With the exclusion of the industry of Coke, Refined Petrolem Products \& Nuclear Fuel.
\end{tabular}

$*=$ With the exclusion of the industry of Coke, Refined Petroleum Products \& Nuclear Fuel.

To emphasise the key role that, in all the countries, is played by the most R\&D-intensive industries, table 2 reports the shares on total manufacturing expenditures performed by Chemicals \& Pharmaceuticals, Electrical \& Optical Equipment and Transport Equipment. By averaging the figures in 1980-2002, these three industries account for a share of total manufacturing research ranging from $73 \%$ in Spain to $83 \%$ in Italy. Another interesting feature depicted by the same table is that, in some countries, the relative importance of these industries has remarkably changed over time. This is especially the case of US and Germany: starting from 1995, in the US the role of leading industry has passed from Transport to Electrical Equipment while the opposite has occurred in Germany. Reminding that the industry of Electrical Equipment encompasses the overwhelming majority of ICT products (semiconductors, electronic components and goods, computers and peripherals, communication equipment), it emerges that almost $37 \%$ of the total manufacturing R\&D performed in the US over 1995-2002 comes from such an industry. During the same period, none of the other countries had a similar composition of industrial research; on the contrary, comparing 1995-2002 with the previous fifteen years, it emerges that especially in Germany but also in France and Spain the R\&D share of Electrical Equipment has decreased over time. As already said, German R\&D has substantially shifted towards Transport Equipment while in Spain there has been a mounting role exerted by Machinery. In France, instead, a rising share has been 
recorded by the Chemicals and Pharmaceuticals industry. Italy is the only European country experiencing a modest shift in favour of the industry containing ICT products while it has significantly reduced the contributions coming from Chemicals and Pharmaceuticals and Transport Equipment. As a final remark, it should be noticed that, over time, the US and Germany have increased the concentration of $\mathrm{R} \& \mathrm{D}$ in the most research-intensive industries while the other countries have recorded a more disperse distribution of research efforts.

Table 2 - Industry shares on total manufacturing R\&D (current prices)

\begin{tabular}{|c|c|c|c|c|c|}
\hline & & $\begin{array}{c}\text { Chemicals \& } \\
\text { Pharmaceuticals }\end{array}$ & $\begin{array}{c}\text { Electrical \& } \\
\text { Optical } \\
\text { Equipment }\end{array}$ & $\begin{array}{c}\text { Transport } \\
\text { Equipment }\end{array}$ & $\begin{array}{c}\text { Total } \\
\text { R\&D-intensive } \\
\text { industries }\end{array}$ \\
\hline \multirow[t]{3}{*}{ US } & 1980-2002 & 15.1 & 30.0 & 32.6 & 77.8 \\
\hline & $1980-1995$ & 14.3 & 27.1 & 35.6 & 77.0 \\
\hline & $1995-2002$ & 17.0 & 36.7 & 25.9 & 79.6 \\
\hline \multirow[t]{3}{*}{ Germany } & 1980-2002 & 21.0 & 28.4 & 29.1 & 78.5 \\
\hline & 1980-1995 & 22.0 & 30.3 & 25.2 & 77.5 \\
\hline & $1995-2002$ & 18.9 & 23.8 & 37.9 & 80.7 \\
\hline \multirow[t]{3}{*}{ France } & 1980-2002 & 19.7 & 32.8 & 31.7 & 84.1 \\
\hline & $1980-1995$ & 18.5 & 33.8 & 32.6 & 84.9 \\
\hline & 1995-2002 & 22.3 & 30.4 & 29.7 & 82.4 \\
\hline \multirow[t]{3}{*}{ Italy } & 1980-2002 & 20.3 & 32.3 & 30.7 & 83.3 \\
\hline & 1980-1995 & 21.6 & 31.9 & 31.3 & 84.8 \\
\hline & $1995-2002$ & 17.5 & 33.1 & 29.5 & 80.1 \\
\hline \multirow[t]{3}{*}{ Spain } & 1980-2002 & 21.1 & 26.3 & 25.8 & 73.2 \\
\hline & 1980-1995 & 21.0 & 27.8 & 25.8 & 74.5 \\
\hline & $1995-2002$ & 21.6 & 22.9 & 25.8 & 70.3 \\
\hline
\end{tabular}

From a dynamic point of view, the different performances across countries can be examined by recurring to the measure of $R \& D$ capital stock described in the previous section, whose changes are assumed to affect the growth of TFP. Figure 1 shows the R\&D capital stock in total manufacturing evaluated at 1995 prices and, for allowing cross-country comparisons, expressed in a common base year $(1995=100)$. For the same variable, table 3 illustrates the average annual rates of change over the entire period and three sub-periods (1980-90, 1990-95 and 1995-2002) characterised by quite different trends.

During 1980-90, all the countries considered had a remarkable expansion of manufacturing R\&D capital: as well emphasised by table 1, Spain and Italy recorded the highest rates of growth 
(respectively, 9 and almost $8 \%$ per annum) and this was consistent with their role of technological follower. Over the first half of the Nineties, instead, there was a marked slowdown of R\&D investment in line with the phase of economic stagnation experienced in most of the advanced countries: the growth rates of R\&D capital declined dramatically in the US, Italy and Germany while France and Spain had a lower reduction. From 1995 on, there has been a significant reprise of R\&D investment in the US which has recorded an annual growth rate of $3.9 \%$, greater than that of France and Germany. The manufacturing knowledge capital of Spain has continued to grow at a very good pace (more than $5 \%$ per year), while Italy has been the only country experiencing a substantial stagnation.

Figure $1-R \& D$ capital stock in total manufacturing $(1995=100)$

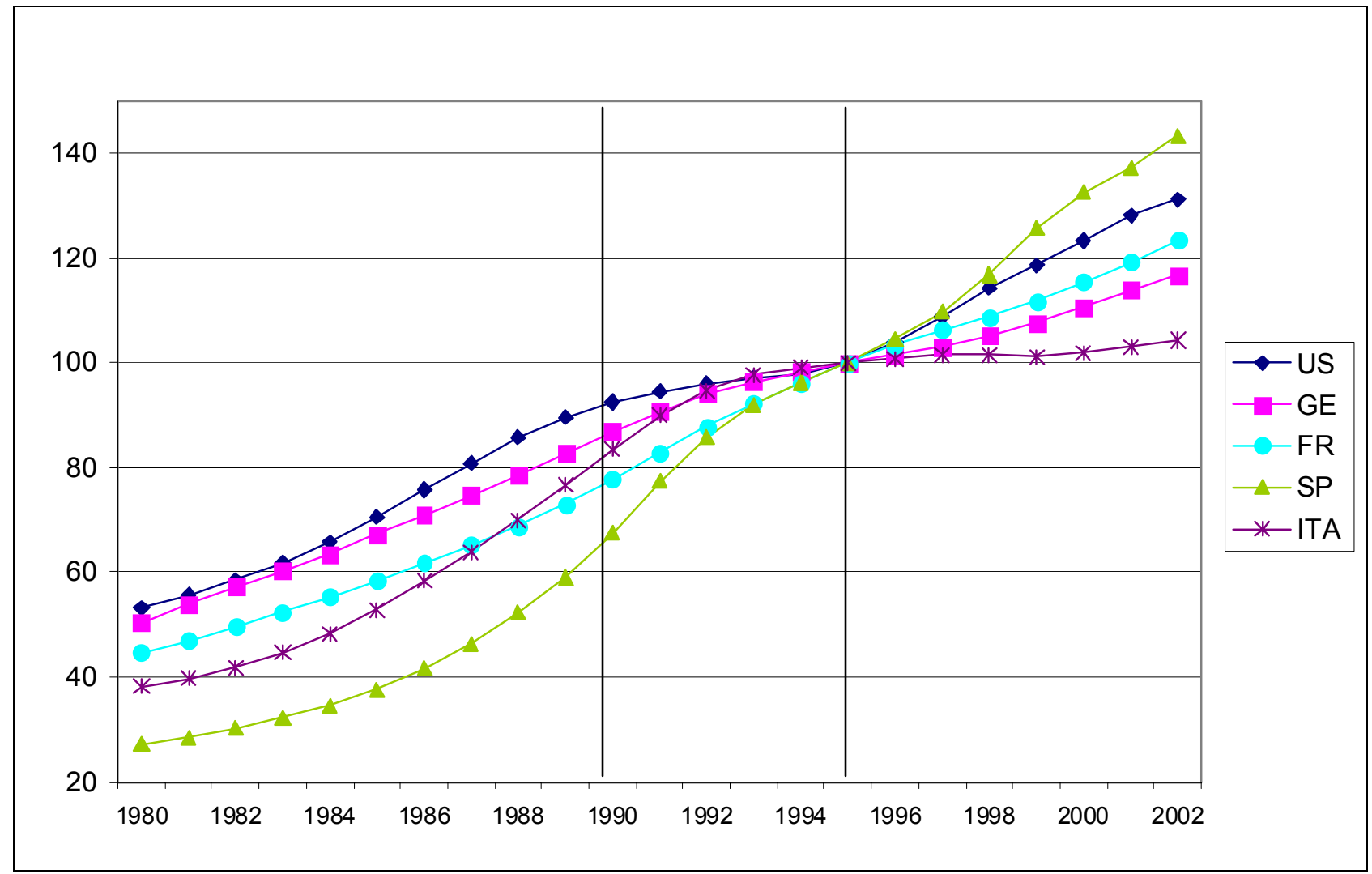

Table 3 - Average annual rates of change in the R\&D capital of total manufacturing

\begin{tabular}{lccccc} 
& United States & Germany & France & Spain & Italy \\
\hline $1980-2002$ & 4.10 & 3.81 & 4.63 & 7.54 & 4.57 \\
\hline $1980-90$ & 5.51 & 5.42 & 5.57 & 9.07 & 7.84 \\
$1990-95$ & 1.57 & 2.84 & 5.01 & 7.85 & 3.60 \\
$1995-2002$ & 3.88 & 2.21 & 3.00 & 5.14 & 0.60 \\
\hline
\end{tabular}


It must be pointed out that the above aggregate trends are the result of quite different performances at industry level. In Appendix 2 we provide a graphical representation of the R\&D capital stock concerned with the three already mentioned research-intensive industries and that of Machinery. Comparing the different trends, it clearly emerges that, from 1995 to 2002, the significant increase of R\&D capital stock in the US manufacturing is almost entirely due to the industry of Electrical \& Optical Equipment. Over the same years, the positive R\&D performance of Germany has been mainly due to Transport Equipment, while France has recorded relatively high rates of growth in Chemicals \& Pharmaceuticals. Spain has performed very well in all the examined industries and, in terms of growth rates, it has ranked first in Chemicals \& Pharmaceuticals and Machinery. Finally, the Italian stagnation in manufacturing R\&D capital must be imputed to the reductions experienced in Chemicals \& Pharmaceuticals and Transport Equipment.

To summarise, the main findings arising from the descriptive analysis carried out in this section are the following. The US, as opposed to Germany and France, have maintained the lead in manufacturing R\&D by concentrating, over the last years, their research efforts in the ICT industry. Spain, albeit remaining a backward country in terms of R\&D intensity, has behaved as a typical technological follower might do, i.e. in almost all the industries it has continuously increased its R\&D investment. Italy, contrary to the experience of all the other countries and in spite of being a follower like Spain, has reduced its research efforts, especially in two of the most R\&D-intensive industries.

\section{Estimation procedure and results across countries}

In this section we perform an estimation of the long-run relationship between TFP and R\&D capital stock. Such a relationship, described in equation [2] of section 3, is investigated, across industries and over time, by means of an Autoregressive Distributed Lags model, ARDL(1,1), of the following type:

$$
\ln T F P_{i t}=\alpha_{0 i}+\alpha_{1} \ln T F P_{i t-1}+\alpha_{2} \ln R D_{i t-1}+\alpha_{3} \ln R D_{i t-2}+\varepsilon_{i t}
$$

in which all the parameters are assumed to be homogenous among industries aside from an individual fixed effect $\left(\alpha_{0 \mathrm{i}}\right)$.

Equation [3] can be then re-formulated as a dynamic panel Error Correction Model (ECM), that is:

$$
\Delta \ln T F P_{i t}=\beta_{0 i}+\beta_{1} \Delta \ln R D_{i t-1}+\beta_{2} \ln T F P_{i t-1}+\beta_{3} \ln R D_{i t-2}+\varepsilon_{i t}
$$

where $\beta_{0 \mathrm{i}}=\alpha_{0 \mathrm{i}}, \beta_{1}=\alpha_{2}, \beta_{2}=\alpha_{1}-1=\alpha_{2}$ and $\beta_{3}=\alpha_{2}+\alpha_{3}$. 
The ratio $\theta=-\left[\beta_{3} / \beta_{2}\right]$ is the long-run elasticity of TFP with respect to $\mathrm{R} \& \mathrm{D}$ capital, while $\beta_{1}$ reflects the short-run variations between the dependent and the explanatory variable, and $\beta_{0 \mathrm{i}}$ denotes industry fixed effects.

Although with different versions, the above framework has been already used to analyse the longrun relationship between R\&D and TFP at industry level. Añón Higón (2007) employs an ECM to distinguish the short- and long-run impact of R\&D capital on the TFP of eight UK manufacturing industries examined over 1970-97. Cameron (2005) uses a similar framework to estimate the impact of R\&D and human capital on the productivity gap between eleven Japanese and US industries observed during 1963-1989. Brandt (2007) applies an ECM to the cost functions of twenty-three manufacturing industries concerned with six major OECD countries (US, Canada, Japan, Germany France and Italy) and examined from 1980 to 1998; for each industry he obtains the long-run elasticity of costs with respect to R\&D capital, whose absolute value is a proxy ${ }^{5}$ of the parameter $\theta$ arising from the single industry estimates of equation [4].

All the above mentioned studies use the SUR (Seemingly Unrelated Regression) estimation method which corrects the covariance matrix of residuals for the contemporaneous correlation that may arise among sectors; since TFP changes are likely to be influenced by stochastic shocks which affect to a different extent the various industries (depending on their technological proximity, degree of exposure to foreign competition, etc.), the SUR estimator turns out to be more efficient than those based on least squares with common time controls. In the following analysis we employ the same method to estimate - separately for each of the five countries considered - the ECM of equation [4] across twelve manufacturing industries over the period 1980-2002.

Before that, we tested whether the series on TFP and R\&D capital stock contain unit roots as well as the presence of a stationary relationship among them over the long-run (cointegration). If the above conditions hold, it will be more informative and appropriate to focus on the long-run R\&D elasticity $(\theta)$ since the coefficient of the first-differentiated $R \& D$ variable $\left(\beta_{1}\right)$ will merely capture the short-run co-movement between the same variables.

In what follows we employ the test developed by Pesaran (2007) to verify whether, for each country, TFP and R\&D capital (taken in log-levels) are non-stationary within the panel of industries. Such a test relaxes the assumption of independence so that it is more robust to the presence of cross-industry correlation than the previous generation of panel tests (see, for a survey, Breitung and Pesaran, 2005). With a view to check the null hypothesis that all the individual series have unit roots, the Pesaran's test is carried out on single-industry ADF-type regressions and, then, 
averaged across industries; in this way, it preserves, as much as possible, the heterogeneity of parameters.

Table 4 - Panel unit roots and cointegration tests

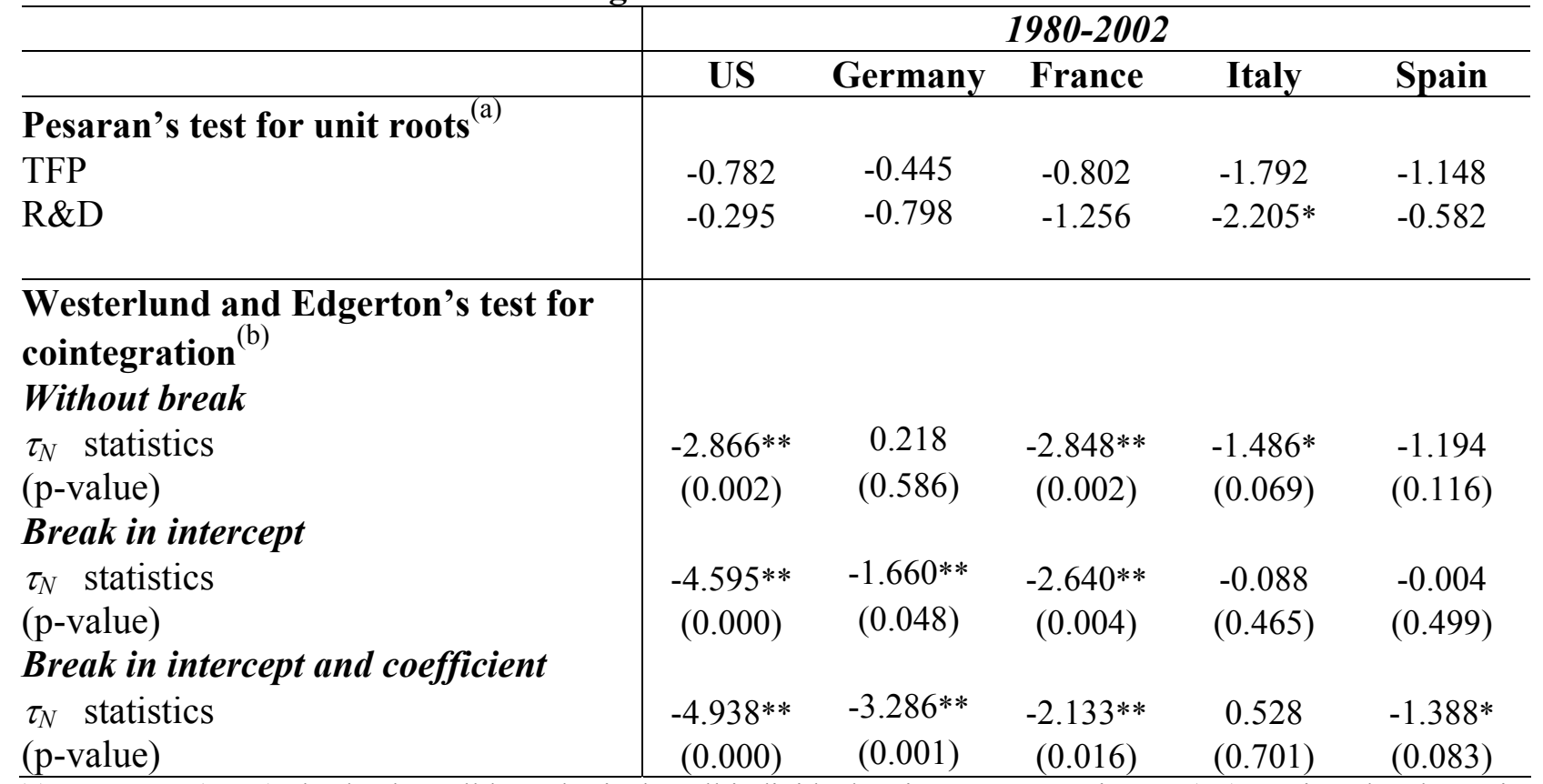

(a) = Pesaran (2007) checks the null hypothesis that all individual series are non-stationary $\left(\mathrm{H}_{0}\right)$, against the alternative of heterogeneity (H1). Under H1 the statistics test diverges to a negative infinite (tabulated 5\% critical value: -2.25).

(b) = Westerlund and Edgerton (2006) check the null hypothesis that there is no cointegration within the panel. The statistics test is distributed as a one-sided standard normal (5\% critical value: -1.64$)$.

$* *=$ Significant at a $5 \%$ level of confidence. $*$ = Significant at a $10 \%$ level of confidence.

The top part of Table 4 shows that all our series are non-stationary at the standard level of confidence $(5 \%)$. Hence, we proceed to verify the presence of cointegration between productivity and knowledge capital by following Westerlund and Edgerton (2006) ${ }^{6}$. They propose a general test statistics $\left(\tau_{N}\right)$ that controls for a broad set of econometric issues: heteroskedaticity, serially correlated errors, cross-sectional dependence and unknown breaks. From the bottom part of Table 4 it emerges that when the presence of structural breaks is not taken into consideration, the statistics $\tau_{N}$ rejects the null hypothesis of no cointegration for the US, France and Italy, but not for Germany ${ }^{7}$ and Spain. However, favourable evidence for Germany emerges when we control for the presence of shifts in the intercept, and the same applies to Spain when a shift of regime over time is allowed, i.e. a break either in the intercept or slope. As a final remark, it should be noted that for the two

\footnotetext{
${ }^{5}$ Actually, the estimates provided by Brandt derive from a cost function taken as the dual of a production function based on gross output (i.e. including material inputs along with labour, tangible capital and R\&D capital); as a consequence, his findings cannot be rigorously compared to those derived from a value added production function.

${ }^{6}$ We thank Joakim Westerlund for providing us with the GAUSS codes used to implement his panel tests.

${ }^{7}$ It should be reminded that the method used to build the German series for the pre-1991 period excludes any noise due to the reunification process. Industry data before 1991 have been indeed constructed from the levels of the Unified
} 
technological backward countries included in our analysis - Italy and Spain - the presence of cointegration is detected only at a $10 \%$ level of confidence, reflecting the relative weakness of the investigated relationship across their manufacturing industries.

Table 5 - Panel ECM estimates of the R\&D impacts on TFP uncorrected

\begin{tabular}{lcccc}
\hline & & & & Long-run R\&D elasticity \\
& $\beta_{1}$ & $\beta_{2}$ & $\beta_{3}$ & $\theta=-\left[\beta_{3} / \beta_{2}\right]$ \\
\hline United States & $0.750^{* *}$ & $-0.184^{* *}$ & $0.093^{* *}$ & $0.508^{* *}$ \\
& $(0.000)$ & $(0.000)$ & $(0.000)$ & $(0.000)$ \\
\hline Germany & $0.131^{* *}$ & $-0.177^{* *}$ & $0.050^{* *}$ & $0.286^{* *}$ \\
& $(0.045)$ & $(0.000)$ & $(0.000)$ & $(0.000)$ \\
\hline France & 0.076 & $-0.010^{* *}$ & $0.023^{* *}$ & $0.232^{* *}$ \\
& $(0.217)$ & $(0.000)$ & $(0.022)$ & $(0.006)$ \\
\hline Spain & 0.054 & $-0.227^{* *}$ & $0.050^{* *}$ & $0.221^{* *}$ \\
& $(0.239)$ & $(0.000)$ & $(0.000)$ & $(0.000)$ \\
\hline
\end{tabular}

** = Significant at a $5 \%$ level of confidence. $*=$ Significant at a $10 \%$ level of confidence.

Moving to the SUR estimate of the ECM described in equation [4], it should be added that we make a small-sample adjustment to calculate the covariance matrix of residuals. Table 5 only presents the estimates of the $\beta$ parameters (industry fixed effects are not reported for the sake of brevity) and the derived parameter $\theta$ which, representing the (long-run) elasticity of TFP with respect to R\&D capital, is crucial in our study. The (non-linear) test of significance of $\theta$ is carried out with the deltamethod and the relevant statistics is distributed as a $\chi^{2}(1)$; for this reason Table 5 reports, in brackets, the $\mathrm{p}$-values associated to this test and to the t-statistics concerned with the $\beta$ parameters.

Starting from the US, both the short-run and long-run elasticity of TFP with respect to R\&D capital are large (0.75 and 0.51$)$ and highly significant, suggesting that, in this country, the productivity of manufacturing industries is particularly sensible to the changes in knowledge capital. The long-run impact of R\&D arising for German and French industries is lower than that estimated for the US and the same happens, to a greater extent, to the short-run parameters (which, moreover, turn out to be barely or not significant).

The results for Italian industries point to the presence of a weak, albeit statistically significant, relationship between R\&D capital and TFP changes: in particular, the long-run impact of R\&D is 
half of that estimated for Germany and three times lower than that obtained for the US. To be stressed is that the long-run elasticity of Italy is smaller than that arising for Spain (0.22) which, by contrast, turns out to be lined up to the values estimated for the other European countries.

It is noteworthy that the above outcomes are comparable to the estimates provided by other studies. Using data for twenty-two manufacturing industries in fourteen OECD countries over the period 1972-94, Frantzen (2002) estimates an elasticity of TFP with respect to R\&D equal to 0.34 . Zachariadis (2004) considers seven industries in ten OCED countries over 1973-95 and obtains, by using different time lags for the R\&D variable, an elasticity ranging from 0.24 to 0.31 . The above values can be viewed as the 'mean' R\&D impact concerned with a sample of developed economies and, thus, they appear quite consistent with our country-specific long-run parameters ${ }^{8}$.

To be stressed is the finding concerned with Spain which is relevant for two main reasons: first, to our knowledge, is was not emphasised in previous studies, also because little or no attention has been devoted to this country; secondly, it suggests that also a country classified as a technological follower may have a remarkable impact of $R \& D$ on productivity. Such an outcome is particularly important for the purpose of our study. If the R\&D elasticity arising for Spain had been equal or lower than that of Italy, one could have reached the conclusion that the long-run impact of R\&D on TFP rises with the intensity of knowledge capital. In other words, probably thanks to the increasing returns due to intra-industry $R \& D$ spillovers, the countries which, in some industries, overcome a given threshold of knowledge capital would obtain, as compared to their less R\&D-intensive counterparts, more than proportional benefits. The result for Spain is at odds with the above interpretation and suggests that the country differences in terms of long-run R\&D elasticity cannot be exclusively associated with the relative intensity of $R \& D$ capital but are also due to its relative changes. Accordingly, the R\&D-induced enhancement of TFP arising for Italian manufacturing industries is the lowest one not because they invest (relatively) little in research but because, over the time span considered, they have invested in R\&D at decreasing rates (see figure 1 and table 1 in the previous section and Appendix 2).

Being derived from the estimates of a very basic model - relying on a unique explanatory factor and a raw measurement of TFP - the above considerations should be taken with caution. Along with that of neglecting the role of international and domestic R\&D spillovers (see the concluding section), a shortcoming of the previous analysis is that the TFP variable is not adjusted for the degrees of utilization and the quality changes in labour and tangible capital and, thus, could be affected by

\footnotetext{
${ }^{8}$ For UK manufacturing industries Añón Higón (2007) estimates a 0.38 long-run R\&D elasticity (while the short-run one is not significant). Once again, being between the values estimated for Germany and the US, the long-run parameter concerned with the UK is in line with our findings.
} 
measurement errors. In the next section we address, although for the Italian case only, some of the measurement problems which might affect the results of our productivity regressions.

\section{A supplement of analysis for the Italian case}

In this section we conduct a further and in-depth inspection of the Italian case by amending the previous analysis in two directions, both of them allowed by the possibility of collecting the required industry data for this country only. Obviously, the same extensions should be applied to all the countries considered in the previous study but, unfortunately, we are not able to accomplish this task because of the lack of consistent data.

Firstly, the raw measure of TFP employed in the previous estimate is adjusted for the degree of utilisation and the quality changes of labour and capital. Secondly, we employ industry data for a longer period of time, i.e. from 1970 to 2002, with a view to obtain more information on the longrun relationship between productivity and knowledge capital.

With respect to labour input, instead of employed people, we use the number of full time equivalent (FTE) employed persons, which is a better (though not the best ${ }^{9}$ ) proxy for the effective utilisation of labour. Moreover, we adjust such a measure for quality changes by using the white/blue collars' ratio at industry level, taken from the surveys on Italian manufacturing firms carried out by Mediocredito Centrale-Capitalia ${ }^{10}$. This correction is aimed at avoiding the risk that the long-run coefficient of $R \& D$ might pick up the increase in the workforce skill occurred during the period considered. Our quality-adjusted measure of labour is computed by augmenting the number of FTE employed persons $(\tilde{L})$ with the share of white collars on total employment $(w)$ that is:

$$
\widetilde{\widetilde{L}}_{i, t}=\widetilde{L}_{i, t} *\left(1+w_{i, t}\right)
$$

This correction implies the assumption that white collars have a marginal productivity two times higher than that of blue collars. Although, this hypothesis seems quite strong at a first sight, it must be stressed that the estimate of the long-run R\&D elasticity does not significantly change when a different productivity ratio is applied (1.5 or 3 instead of 2). It should be added that this kind of correction is more suitable for the Italian case than that implemented, for instance, by Griffith et al. (2004). Under the hypothesis of perfectly competitive labour markets, they obtain a quality-adjusted

\footnotetext{
${ }^{9}$ The most appropriate indicator of labour usage is the number of hours worked which, however, is not provided by official statistical sources at industry level and for the time span considered in the present study.

${ }^{10}$ This dataset collects data on a stratified sample representative of the Italian manufacturing firms having between 10 and 499 employees, while it covers the entire population of larger firms. From 1970 to 1989, the white/blue collars' ratio has been interpolated among four benchmark years $(1968,1973,1978$, and 1984) while for the subsequent years annual data are available. In order to smooth the series, a three-year moving average has been used.
} 
measure of labour input by weighting each group of workers with the corresponding wage bill ${ }^{11}$. However, at least until the early Nineties, the high bargaining power of the Italian trade unions did not allow that the wages of white collars were too far from those of blue collars; as a consequence, since the changes in relative wages were modest and not particularly affected by those in relative productivity, the correction proposed by the above authors may produce misleading results ${ }^{12}$.

Moving to capital input, as in Griffith et al. (2004), our measure of capital adjusted for its degree of utilisation is

$$
\widetilde{K}_{i, t}=K_{i, t} *\left(1+\frac{Y_{i, t}-\hat{Y}_{i, t}}{\hat{Y}_{i, t}}\right)
$$

where $Y_{i, t}$ is the industry valued added at constant prices and $\hat{Y}_{i, t}$ is the fitted value which arises from regressing, for each separate industry, the real value added on a constant and a time trend.

Following Jorgenson et al. (1987), an indicator of capital quality $(q)$ has been obtained from the newly available industry series on investment types released by ISTAT (see Appendix 1), computed as the ratio between the capital stock evaluated respectively at rental $(R)$ and market prices $(p)$ :

$$
q_{i, t}=\frac{\sum_{j=1}^{9} R_{i j, t} K_{i j, t}}{\sum_{j=1}^{9} p_{i j, t} K_{i j, t}}, \quad R_{i j, t}=p_{i j, t}\left(r_{i, t}+\delta_{i j}-\pi_{i j, t}\right), \quad \pi_{i j, t}=\frac{p_{i j, t}-p_{i j, t-1}}{p_{i j, t-1}}
$$

where, in this case, the suffixes $i$ and $j$ denote respectively industries and types of asset ${ }^{13}, r$ is the nominal rate of return ${ }^{14}, \delta$ denotes the asset specific depreciation rate (obtained as described in section 3), and $\pi$ is the rate of change of the investment prices. To be stressed is that the difference between $R$ and $p$ reflects the substitution towards assets with relatively high marginal products as they are characterized by a relatively high physical deterioration and economic obsolescence. This adjustment should avoid that $\theta$ captures the qualitative growth of tangible capital, fuelled by the

${ }^{11} \widetilde{\widetilde{L}}_{i, t}=W_{i, t}{ }^{S} B_{i, t}{ }^{1-S}$ where $W$ and $B$ are respectively the number of white- and blue-collar FTE workers, s and 1-s their wage bills. A more elaborated procedure is that used by Brandolini and Cipollone (2001) who computed a qualityadjusted measure of labour input by distinguishing Italian workers in five educational levels, weighted by their respective average wages. For the whole Italian economy, the inclusion of such a measure reduced substantially the contribution of TFP to the growth of value added over 1977-2000.

${ }^{12}$ Unreported findings confirm this expectation. With respect to the measure computed by Brandolini and Cipollone (see the previous footnote) we were not able to test its adequacy because, for Italy, data on the educational attainments of workers are not available at the level of manufacturing industries.

${ }^{13}$ ISTAT disentangles gross fixed capital formation into the following nine categories: machinery, office machinery, communication equipment, furniture, vehicles, other transport equipment, buildings, software, and other equipment.

${ }^{14}$ The nominal rate of return is estimated internally from ISTAT industry accounts by recurring to the following (expost) formula:

$$
r_{i, t}=\frac{G O S_{i, t}-\sum_{j=1}^{9}\left(\delta_{i j}-\pi_{i j, t}\right) p_{i j, t} K_{i j, t}}{\sum_{j=1}^{9} p_{i j, t} K_{i j, t}}
$$


rising adoption by manufacturing firms of technologically advanced capital as computers, communication equipment and software. Accordingly, our measure of quality-adjusted capital is:

$$
\overline{\widetilde{K}}_{i, t}=\widetilde{K}_{i, t} *\left(1+q_{i, t}\right)
$$

Summing up, the adjusted measure of TFP (in logs) is given by:

$$
\ln T \widetilde{\widetilde{F}} P_{i t}=\ln Y_{i t}-s_{L i} \ln \widetilde{\widetilde{L}}_{i, t}-\left(1-s_{L i}\right) \ln \widetilde{\widetilde{K}}_{i, t} \quad \text { (cf. equation [2], section 3). }
$$

Table 6 - Impact of R\&D capital on TFP: Italian manufacturing industries ${ }^{\circ}$

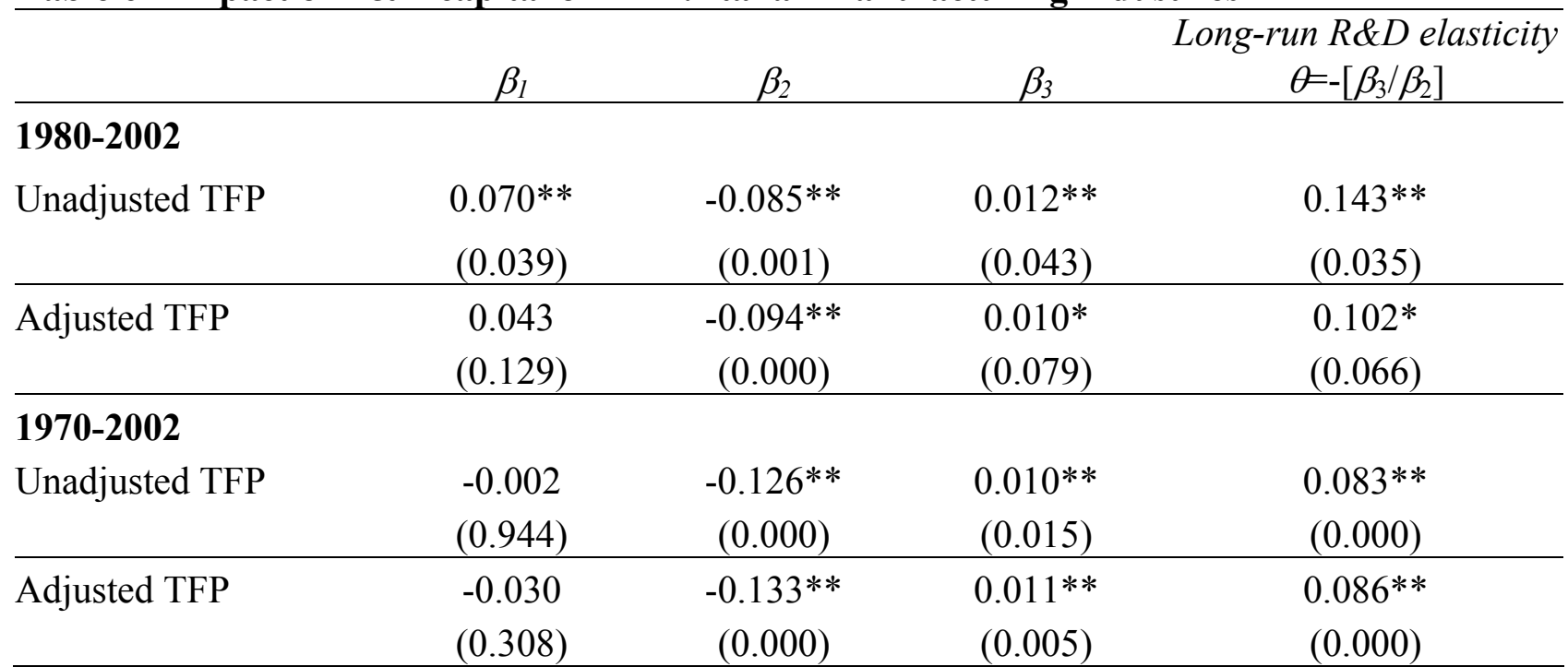

${ }^{\circ}=$ SUR estimates with 12 manufacturing industries over the periods 1980-2002 and 1970-2002. P-values in brackets.

$* *=$ Significant at a $5 \%$ level of confidence. $*=$ Significant at a $10 \%$ level of confidence.

The top part of Table 6 still refers to the period 1980-2002 and compares the results obtained, respectively, with the raw and the adjusted measure of TFP. Along with a remarkable decrease of $\beta_{l}$ (which, moreover, becomes not significant), the undertaken adjustments also reduce the long-run R\&D elasticity by almost a third, from 0.14 to 0.10 . A provisional interpretation of the latter finding is that, over 1980-2002, the efforts concerned with R\&D and those aimed at enhancing the quality of labour and capital have complemented each others so that, when TFP is not adjusted, the R\&D capital variable captures to a some extent these quality changes as well.

The estimates reported in the bottom part of Table 6 refer to a quite longer period of time (33 versus 23 years) and, since our study is centred on the long-run impact of $R \& D$, they should be considered more reliable and informative than the previous ones. Indeed, the statistical significance of the longrun elasticity of TFP with respect to $R \& D$ sensibly improves, but the size of its coefficient decreases from 0.102 to 0.086 when the TFP measure is adjusted, and from 0.143 to 0.083 otherwise. In conclusion, the additional analyses carried out in this section confirm that among 
Italian manufacturing industries the relationship between $R \& D$ and productivity growth is particularly weak.

\section{Discussion of results, policy implications and analytical extensions}

The main finding of the present paper is that, at industry level, the relationship between $R \& D$ and manufacturing productivity is quite heterogeneous among developed countries. This distinguishes our analysis from the majority of previous studies which, instead, have examined single economies or pooled data across industries and countries of the OECD area.

Our panel ECM estimation, referring to 1980-2002, gives rise to a high (excess) elasticity of TFP with respect to R\&D capital in the US (around 0.51 percent); lower values emerge for Germany (0.29), France (0.23) and Spain (0.22), followed by Italy which records the lowest R\&D elasticity (0.14). The weak relationship between R\&D and TFP across Italian manufacturing industries is confirmed (and even reinforced) when the TFP measure is adjusted for the degree of utilisation and the quality changes of labour and capital inputs, as well as when the ECM is estimated over the period 1970-2002.

Although based on a simple and one-dimensional framework, the above findings highlight that, across countries, there are uneven capabilities to translate the internally generated knowledge into economic and productivity growth. In the following, we first discuss the different performances of the US as opposed to the EU industries and, then, concentrate the attention on the peculiar case of Italy.

The fact that across German, French and Spanish industries the long-run impact of R\&D on TFP is about half that recorded in the US is probably due to the leading role still played by the latter country. As documented in section 4, over the examined period, the US have always ranked first in terms of R\&D either in manufacturing as a whole or in the most research-intensive industries. European industries (with the exception of the Italian ones) have remarkably increased their R\&D outlays but, in terms of R\&D capital (i.e. cumulative investment), their distance from the US has remained very pronounced. Thus, European countries are still relying on a lower knowledge base which implies that, in most industries and especially the more dynamic ones, they are not able to shift the technological frontier and reap the typical extra-benefits attainable by technological leaders. In fact, the US leadership has remained strong thanks to the recent R\&D performance of Electrical \& Optical Equipment (cf. section 3): this industry includes the bulk of ICT products and has been one of the main driver of the productivity revival experienced in the US during the second half of the Nineties (Jorgenson, 2005). In this core industry of the so called 'digital economy', the 
R\&D capital growth performed by European countries during 1995-2002 has been dramatically lower than that recorded in the US (see Appendix 2, figure A.2).

Taken together, all the above factors could explain a substantial portion of the US-EU divide in terms of R\&D-induced enhancement of productivity. As a consequence, if the above interpretation holds, our findings provide a strong support to the Lisbon strategy in that the EU business sector should undertake exceptional efforts in the field R\&D and take the lead in some knowledge-based industries. Unfortunately, from 2001 to 2005, the R\&D investment in the EU has been stagnating or decreasing (European Commission, 2007) so that, in line with the fundamental revision of the entire Lisbon strategy (cf. European Council, 2005), the ambitious R\&D targets for 2010 have been substantially downsized. According to our findings, this implies that also in the next decade a relevant source of productivity growth will be missed or under-exploited by the EU business sector. The same pessimistic conclusion applies, a fortiori, to the Italian manufacturing sector which, among those of the European countries considered in the present study, has attained the lowest impact of R\&D on the growth of TFP. As already stressed in sections 4 and 5, the disappointing performance of Italy cannot be ascribed to its structural features, i.e. a low-tech specialisation and a strong presence of small firms. Such an explanation is ruled out by the results obtained for Spain, a country characterised by quite similar patterns of specialisation and average size of firms. What emerges for Italy from 1990 onwards is a slowdown in the knowledge accumulation process; this seems the only plausible explanation to hand for its lower estimated elasticity of TFP with respect to R\&D capital. Ironically, Italy stopped investing on industrial research just when this factor became crucial to compete in the international market due to, on the one hand, the exhaustion of the advantages of being a technological follower and, on the other, the rising competition from developing countries (mainly based on lower labour costs). Such a reduction or stagnation of R\&D efforts has been particularly intense in two industries which account for the bulk of a country's industrial research: Chemicals \& Pharmaceuticals and Transport Equipment (see Appendix 2, figures A.1 and A.3).

A detailed discussion of the reasons at the roots of the Italian R\&D slowdown is beyond the scope of this paper ${ }^{15}$. However, some of them are worth, at least, to be mentioned. First, starting from the early Nineties, large state-owned companies - belonging, in particular, to the chemical and electronic industries and accounting in 1990-91 for about one third of the R\&D performed by the whole manufacturing sector - have been restructured and, then, partially or entirely privatised. These processes have induced a substantial downsizing or dismissal of many large R\&D laboratories that have not been replaced by those of established or emerging high-tech companies. 
On the contrary, Olivetti, one of the major European producers of office machinery, entered in a deep crisis in 1994 and, gradually, went out of the IT market. With a few partial exceptions, during the Nineties all the large Italian companies (including Fiat) have reduced, for different reasons, their R\&D investment and the industry data used in our empirical analysis are a clear reflection of their behaviour. According to the ISTAT surveys, starting from the late Nineties an increasing number of small and medium-sized firms have been involved in formal R\&D activities but, due to their limited financial resources, their cumulated research investment has only marginally compensated for the R\&D drop of large companies (Sterlacchini, 2004).

With respect to the difficulties of Italian enterprises to perform innovative activities, some recent studies have stressed the role played by financial constraints. For a large sample of Italian manufacturing firms, Huynh and Rotondi (2007) find that the local degree of banking development does not exert a significant impact on the intensity of R\&D expenditures. Benfratello et al. (2005) and Alessandrini et al. (2007) show that the local supply of bank loans is positively associated with process innovations while it does not significantly affect the firms' propensity to innovate their products. This is probably due to the collaterals required by Italian banks: in effect, while process innovations are mainly based on acquisitions of new machinery, product improvements rest on intangible investments (such as R\&D) which do not give rise to the tangible assets that can be used as collaterals. Faini and Sapir (2005) highlight a similar bias in the investment behaviour of Italian firms by stressing that, over the Nineties, their investments in physical capital increased while the same did not occur for those in intangible assets. The low propensity of the Italian banks to finance innovative firms is particularly worrisome in light of the scarce development of venture capital. Both factors hinder the growth of high-tech start-ups which, as incubators of technological advancements and/or organizational changes, are crucial for sustaining the aggregate productivity growth of a country (Bassanini and Scarpetta, 2002).

Also the other European countries probably share the drawbacks of having a financial system and, broadly speaking, an institutional climate less favourable to high-tech ventures, but the problem faced by Italy seems much more severe because the same shortcoming is coupled, as already stressed, with a declining commitment to R\&D by its largest established companies. Thus, strong and urgent policy interventions are needed to both reverse the trend experienced by large firms and sustain the growth of small technology-based firms. To yield substantial productivity benefits in a relatively short period of time, such a complex and 'extra-ordinary' policy framework should be particularly oriented towards the most R\&D-intensive industries, where a sufficient knowledge base already exists.

\footnotetext{
${ }^{15}$ For an in-depth analysis of the problematic prospects faced by the Italian high-tech industries during the early
} 
As a final remark and with a view to suggest some possible extensions of the present analysis, it must be pointed out that the scope of this work has been limited to gauge the direct (withinindustry) effect of knowledge capital on TFP. Although such an effect plays a pivotal role, there are two further channels through which R\&D may enhance productivity. First, R\&D activities are also aimed at sustaining an adequate absorption capacity which allows a country (or industry) to remain as close as possible to the technological frontier (Cohen and Levinthal, 1989). Accordingly, the TFP dynamic also depends on the distance from the technological leader; by interacting the R\&D capital with a proxy of such a distance it is possible to infer whether innovation activities facilitate the absorption of foreign knowledge, along with directly affecting productivity. By pooling industry data from several OECD countries, Griffith et al. (2004) implement the above framework: although single country parameters are not directly estimated, they infer that, for Italy, $40 \%$ of the overall impact of R\&D on TFP - measured in terms of rate of return - is accounted for technology transfer ${ }^{16}$. Secondly, the productivity effects of research activities may spill over across industries and countries. Generally, inter-industry (within-country) externalities are detected by introducing into a TFP regression an external knowledge stock, obtained by weighting the R\&D capital of other industries according to either the inter-industry flows of intermediate goods provided by inputoutput tables (Añón Higón, 2007) or a patent-based matrix of technology flows (Frantzen, 2002). With respect to international $R \& D$ spillovers, starting from the seminal contribution of Coe and Helpman (1995), they are usually taken into account by using a stock of foreign R\&D built on bilateral import shares. Both kinds of spillovers - within and between countries - are considered in a recent study concerned with the manufacturing industries of six OECD countries (Brandt, 2007).

To implement these additional analyses for all the countries and industries considered in the present study a broad set of consistent data are needed and, at this stage, we were not able to accomplish such a difficult task. In any case, although some of the above extensions are important to attain a more comprehensive picture of the relationship between R\&D and manufacturing TFP, we believe that they will not substantially affect the policy implications arsing from the estimation of the direct effect of knowledge capital.

Nineties see Bussolati et al. (1996) and Ferrari et al. (1999).

${ }^{16}$ The importance of international transfer is also stressed by Antonelli at al. (2003) who find that, over the period 1963-1997, the dynamic of Italian TFP has been significantly affected by the aggregate outlays for foreign technologies registered in the Technology Balance of Payments. 


\section{References}

Alessandrini P., A. Presbitero and A. Zazzaro (2007) Bank Size or Distance: What Hampers Innovation Adoption by SMEs, Marche Polytechnic University, mimeo.

Añón Higón, D. (2007) The Impact of R\&D Spillovers on UK Manufacturing TFP: A Dynamic Panel Approach", Research Policy, 36: 949-963.

Antonelli, C., R. Marchionatti and S. Usai (2003) Productivity and External Knowledge: the Italian Case, Rivista Internazionale di Scienze Economiche e Commerciali (RISEC), (1): 69-90.

Bassanetti, A., M. Iommi, C. Jona-Lasinio and F. Zollino (2004) La Crescita dell'Economia Italiana tra Ritardo Tecnologico e Rallentamento della Produttività, Banca d'Italia - Temi di Discussione, n. 539.

Bassanini, A. and S. Scarpetta (2002) Growth, Technological Change, and ICT diffusion: Recent Evidence from OECD Countries, Oxford Review of Economic Policy, 18(3): 324-344.

Benfratello L., F. Schiantarelli and A. Sembenelli (2005) Banks and Innovation: Microeconometric Evidence on Italian Firms, Working Papers in Economics 631, Boston College (updated June 2007).

Boeri, T., R. Faini, A. Ichino, G. Pisauro and C. Scarpa (2005) Oltre il declino, Bologna, Il Mulino.

Brandolini, A. and P. Cipollone (2201) Multifactor Productivity and Labour Quality in Italy, Banca d'Italia Temi di Discussione, n. 422.

Brandt, N. (2007) Mark-ups, Economies of Scale and the Role of Knowledge Spillovers in OCED Industries, European Economic Review, forthcoming (doi: 10.1016/j.euroecrev.2006.12.001).

Breitung, J. and M. Pesaran. (2005) "Unit Roots and Cointegration in Panels", in Matyas, L. and P. Sevestre (eds.) The Econometrics of Panel Data (Third Edition), forthcoming, Kluwer Academic Publishers.

Bussolati, C, F. Malerba and S. Torrisi (eds.) (1996) L'evoluzione delle industrie ad alta tecnologia, Il Mulino, Bologna.

Cameron, G. (2005) The Sun Also Rises: Productivity Convergence Between Japan and the USA, Journal of Economic Growth, 10:387-408.

Coe, D. T. and E. Helpman (1995) International R\&D Spillovers, European Economic Review, 39: 859-887.

Cohen, W.M. and D. Levinthal (1989) Innovation and Learning: The Two Faces of R\&D, Economic Journal, 99: 569-596.

Daveri, F. (2004) Why is there a European productivity problem?, CEPS Working Document \#205, July 2004.

Daveri, F. and C. Jona-Lasinio (2006) Italy's Decline: Getting the Facts Right, Giornale degli Economisti e Annali di Economia, 64 (4): 365-420.

European Commission (2005) The Economic Costs of Non-Lisbon: A Survey of the Literature on the Economic Impact of Lisbon-type Reforms, European Economy Occasional Paper16, Brussels.

European Commission (2007) Key Figures 2007 on Science, Technology and Innovation, 11 June 2007, downloaded from http://ec.europa.eu/invest-in-research/monitoring/statistical01_en.htm. 
European Council (2005) Council Recommendation of 12 July 2005 on the broad guidelines for the economic policies of the member States and the Community (2005 to 2008), 2005/601/EC, Official Journal of the European Union, L205/28-37.

Ferrari, S., P. Guerrieri, F. Malerba, S. Marioti and D. Palma (eds.) (1999) L'Italia nella competizione tecnologica internazionale: secondo rapporto, Franco Angeli, Milano.

Faini, R. and A. Sapir (2005) "Un modello obsoleto? Crescita e specializzazione dell'economia italiana", in Boeri, T., R. Faini, A. Ichino, G. Pisauro and C. Scarpa (eds.).

Fachin, S. and A. Gavosto (2007) The Decline in Italian Productivity: A Study in Estimation of Long-Run Trends in Total Factor Productivity with Panel Cointegration Methods, MPRA Paper 3112, University Library of Munich.

Frantzen, D. (2002) Intersectoral and International R\&D Knowledge Spillovers and Total Factor Productivity, Scottish Journal of Political Economy, 49 (3): 280-303.

Griffith, R., S. Redding and J. Van Reenen (2004) Mapping the Two Faces of R\&D: Productivity Growth in a Panel of OECD Industries, Review of Economics and Statistics, 86 (4): 883-895.

Griliches, Z. (1995), "R\&D and Productivity: Econometric Results and Measurement Issues", in Stoneman, P. (ed.), Handbook of the Economics of Innovation and Technological Change, Oxford, Basil Blackwell.

Hall, B. (2006) R\&D, Productivity and Market Value, IFS Working Papers, W06/23.

Hall, B. and J. Mairesse (1995) Exploring the Relationship between R\&D and Productivity in French Manufacturing Firms, Journal of Econometrics, 65: 263-93.

Huynh, K.P. and Z. Rotondi (2007) R\&D Spending, Local Banks, and Knowledge Spillovers, Working paper available at SSRN: http://ssrn.com/abstract $=968666$.

Jorgenson, D.W., Gollop, F.M. and B. Fraumeni (1987) Productivity and U.S. Economic Growth, Cambridge (MA), Cambridge University Press.

Jorgenson, D. W. (2005) "Accounting for Growth in the Information Age", in Aghion, P. and S. Durlauf (eds.) Handbook of Economic Growth, Volume 1A, Amsterdam, North-Holland, 2005, pp. 743-815.

Maffezzoli, M. (2006) Convergence across Italian Regions and the role of Technological Catch-Up, B.E. Journal of Macroeconomics (Topics), 6 (1), article 15.

OECD (2001) Measuring Capital. Measurement of Capital Stocks, Consumption of Fixed Capital and Capital Services, OECD, Paris.

Pesaran, M. H. (2007) A Simple Panel Unit Test in the Presence of Cross Section Dependence, Journal of Applied Econometrics, 22(2): 265-312.

Romer, P. (1990) Endogenous Technological Change, Journal of Political Economy, 98(5): S71-S102.

Sapir, A., P. Aghion, G. Bertola, M. Hellwig., J. Pisani-Ferry, D. Rosati, J. Vinals and H. Wallace (2004) An Agenda for a Growing Europe - The Sapir Report, Oxford, Oxford University Press.

Sterlacchini, A. (2004) Ricerca e alta tecnologia in Italia: le basi per un rilancio, L'Industria, 4: 675-706.

van Ark, B. van, J. Melka, N. Mulder, M. Timmer and G. Ypma (2002) ICT Investments and Growth Accounts for the European Union 1980-2000, Groningen Growth and Development Centre, Research Memorandum GD-56, revised March 2003. 
Venturini, F. (2004) The determinants of Italian slowdown: What do the data say?, EPKE Working Paper $\mathrm{n}$. 29, National Institute of Economic and Social Research, London

Westerlund, J. and D. Edgerton (2006) Simple Tests for Cointegration in Dependent Panels with Structural Breaks, Lund University, July, mimeo.

Wieser, R. (2005) Research and Development Productivity and Spillovers: Empirical Evidence at Firm Level, Journal of Economic Surveys, 19: 587-621.

Zachariadis, M. (2004) R\&D-induced Growth in the OECD?, Review of Development Economics, 8 (3): 423 439.

\section{APPENDIX 1 - Data Sources}

ISTAT, Investimenti fissi lordi per branca proprietaria, stock di capitale e ammortamenti, ottobre 2006: Industry investment in machinery, non-residential buildings, office machinery, communication equipment, furnishing, road transport equipment, other transport equipment, software, buildings, other goods. Reference period: 1970-2002.

ISTAT, Statistiche sulla ricerca scientifica: Business total Research and Development expenditure by industry (billions of liras in current prices). Reference period: 1967-1987.

Mediocredito Centrale-Capitalia, Indagine sulle imprese manifatturiere, 1974-2005: Industry ratio between non-production and production workers. Reference period: 1968, 1973, 1978, 1984, 19892003.

OECD ANBERD, R\&D expenditure in industry (ISIC. Rev.2) Vol. 2002 Release 1 (millions of national currency at current prices). Reference period: 1973-1980.

OECD, Structural Analysis (STAN) database, 2005: Industry Value Added (at current and constant prices), Gross Fixed Capital Formation (at current and constant prices), Total Employment (employees and self-employed, in thousands), Full-Time Equivalent Employment (available for some countries only), Labour Compensation (at current prices), Net and Gross Fixed Capital (at constant prices). Reference period: 1980-2002.

OECD, Science and Technology Database, 2006: Business total Research and Development expenditure by industry (millions of national currency in current prices). Reference period: 1981-86 and 1987-2002. 
APPENDIX 2 - R\&D capital stock for selected industries
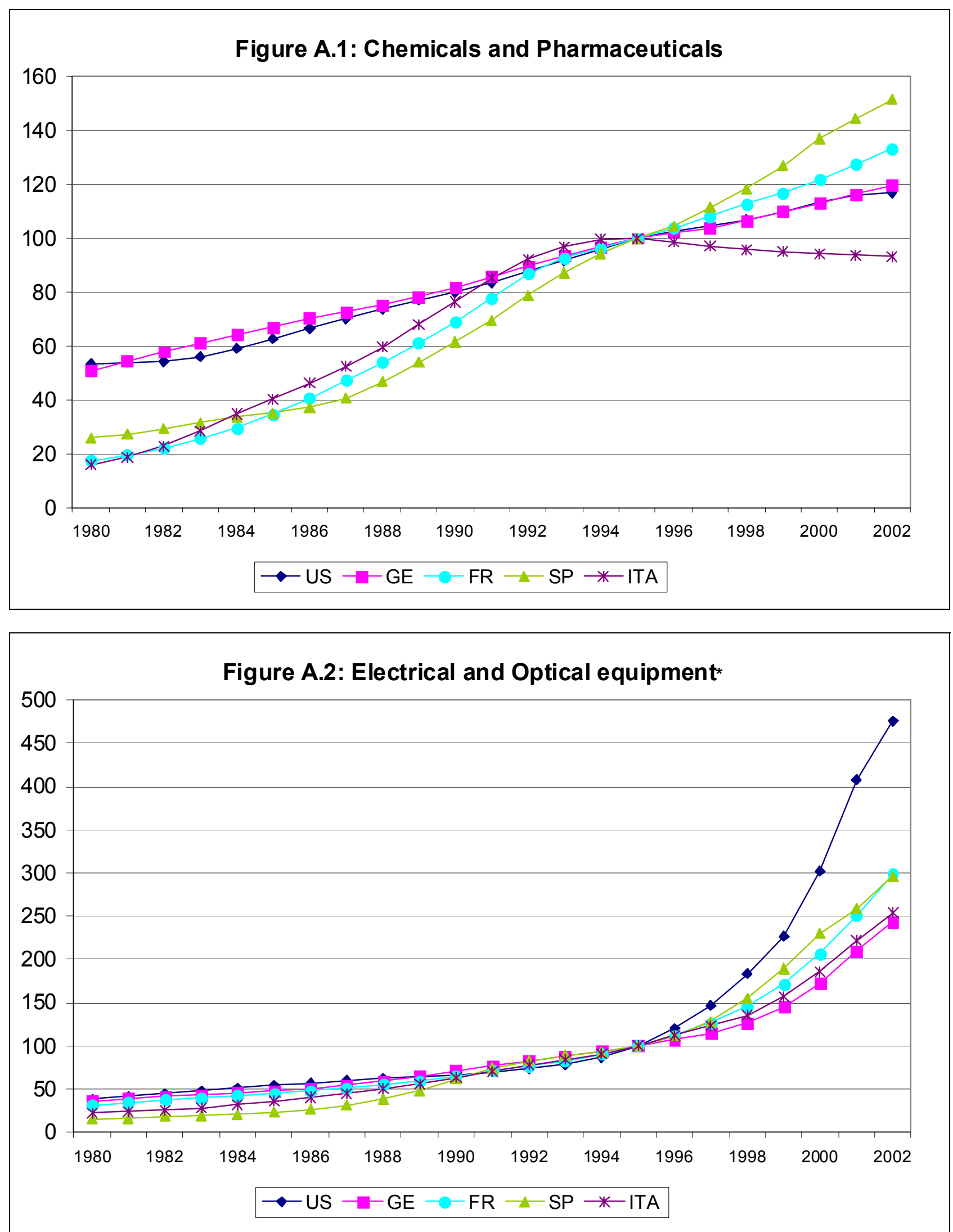

*= All the series are built by applying a harmonised deflator obtained from US hedonic prices adjusted for rate of inflation's differentials. 

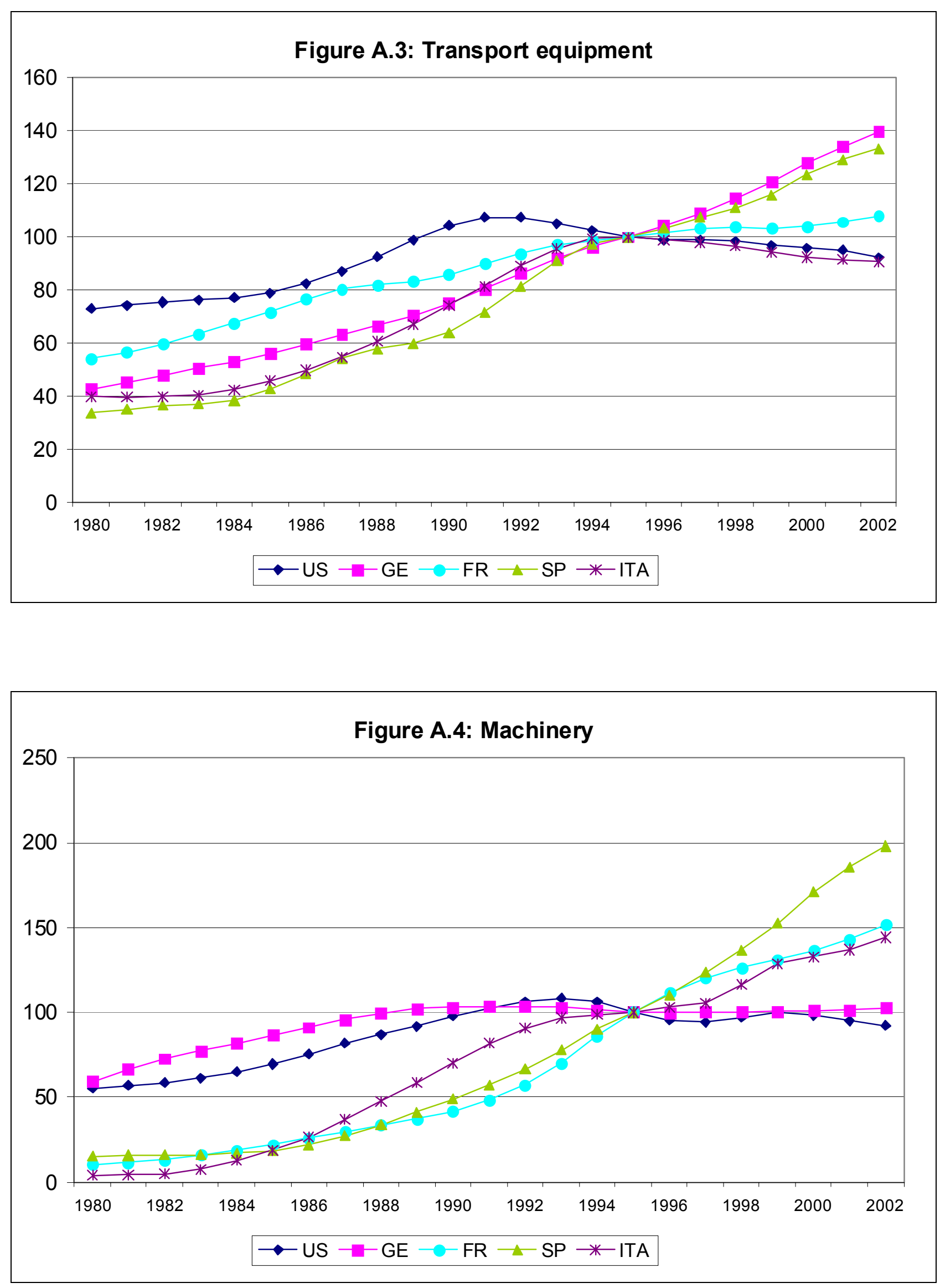